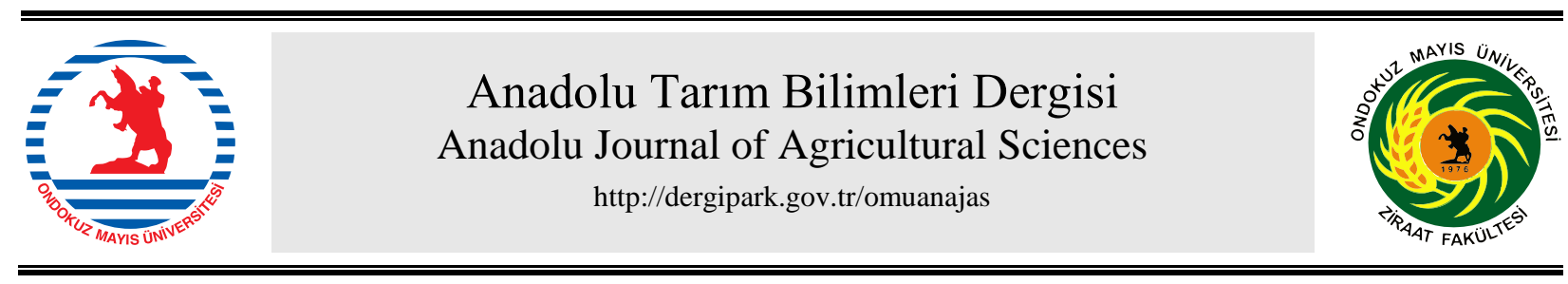

Araştırma/Research

\title{
Çarşamba Ovası'nda işlenen tarım alanlarının bazı fiziksel ve kimyasal toprak özelliklerinin incelenmesi
}

\author{
Nalan Kars ${ }^{\mathrm{a}}$, İmanverdi Ekberli ${ }^{\mathrm{b}^{*}}$ \\ ${ }^{a}$ T.C. Tarım ve Orman Bakanlığl, Karadeniz Tarımsal Araştırma Enstütüsü Müdürlüğü, Samsun \\ ${ }^{b}$ Ondokuz Mayls Üniversitesi, Ziraat Fakültesi Toprak Bilimi ve Bitki Besleme Bölümü, Samsun \\ *Sorumlu yazar/Corresponding author:_iman@omu.edu.tr
}

Geliş tarihi 15.01.2019 Kabul tarihi 24.04.2019

\begin{abstract}
ÖZET
Bu çalışmada, Çarşamba Ovası'nda geleneksel toprak işleme yöntemleriyle ana ürün olarak mısır bitkisi yetiştirilen tarım topraklarının bazı fiziksel ve kimyasal özellikleri araştıılmıştır. Bu amaçla, Samsun ilinde yer alan Çarşamba Ovası'nın 20 köyünde çiftçiler tarafından mısır tarımı yapılan arazilerden toprak örnekleri alınmıştır. Araştırma 2013-2014 yılları arasında aynı arazilerde yürütülmüsştür. Toprak örneklerinde bazı fiziksel (tekstür, tarla kapasitesi, solma noktası, hacim ağırlı̆ı) ve kimyasal (organik madde, toprak reaksiyonu, elektriksel iletkenlik, kireç içeriği, toplam azot, değişebilir katyonlar, yarayışlı fosfor ve potasyum, katyon değişim kapasitesi, alınabilir $\mathrm{Fe}, \mathrm{Cu}, \mathrm{Zn}, \mathrm{Mn}$ ) özellikler belirlenmiştir. Araştırma sonucuna göre, toprakların çoğunluğu killi ve killi tın bünyeye sahip, hacim ağıllı̆̆ değerleri genellikle $1.30-1.51 \mathrm{~g} \mathrm{~cm}^{-3}(\% 52.5$ ' i), \% 60'ının tarla kapasitesi değerleri ise \% 30-50 arasında saptanmıştır. Toprakların büyük bir çoğunluğu (\% 77.5'i) hafif alkalin reaksiyonlu, tuzsuz, az kireç içermekte olup, organik madde miktarları azdan fazlaya değişkenlik göstermiştir. Toprakların azot miktarı düşük (\% 65'i), fosfor miktarı az ( $\left.\% 45^{\prime} \mathrm{i}\right)$; orta ( $\% 20$ 'i); çok yüksek ( $\left.\% 17.5^{\prime} \mathrm{i}\right)$, potasyum düzeyi orta $\left(\% 47.5^{\prime} \mathrm{i}\right)$, katyon değişim kapasitesi ise yüksek (\% 40'i), çok yüksek (\% 50'i) olarak saptanmıştır. Toprakların demir miktarı (\% 92'i) yüksek, bakır miktarı (\% 85'i) çok yüksek, mangan miktarı çok düşük ( $\left.\% 87.5^{\prime} \mathrm{i}\right)$, çinko miktarı ise çok düşük (\% 72.5 'i) düzeyde bulunmuştur. Araştırma topraklarının fíziksel özellikleri (bünye, hacim ağırlığı, tarla kapasitesi) yüksek verim elde edilmesini sınırlandıran faktörler olmamakta, toprakların büyük kısmı azot ve fosfor bakımından zengin olmadığından azotlu ve fosforlu gübreleme yapılması gerekmektedir.
\end{abstract}

Investigation of some physical and chemical soil properties of cultivated fields in Çarşamba Plain

\section{ABSTRACT}

In this study, some physical and chemical properties of maize grown agricultural soils in Çarşamba Plain were investigated. For this purpose, soil samples were taken from agricultural land cultivated by farmers from twenty villages of Çarşamba Plain in Samsun. The study was carried out between 20132014 in the same fields. In the soil samples, some physical (texture, field capacity, wilting point, bulk density) and chemical properties (organic matter, soil reaction, electrical conductivity, lime content, total nitrogen, exchangeable cations, available phosphorus, cation exchange capacity, available $\mathrm{Fe}, \mathrm{Cu}$, $\mathrm{Zn}$ and $\mathrm{Mn}$ ) were determined. According to the results of research, majority of the soils maize crops were grown were determined to have clayey and clayey loam textured, bulk density values generally $1.30-1.51 \mathrm{~g} \mathrm{~cm}^{-3}(52.5 \%)$ and field capacity values of $60 \%$ were found as $30 \%-50 \%$. The great majority of the soils $(77.5 \%)$ had slightly alkaline reaction, low lime contents, nonsaline and amounts of organic matter in the soils varied from low to high. The amounts of nitrogen in the soils were low $(47.5 \%)$ and potassium were medium $(47.5 \%) .45 \%$ of phosphorus was defined as low, $20 \%$ as medium and $17.5 \%$ as high. $40 \%$ of cation exchange capacity was defined as high and $50 \%$ as very high. Amount of iron in the soils were (92\%) high, amount of copper (85\%) was very high, manganese content was very low $(87.5 \%)$ and amount of zinc was very low $(72.5 \%)$. The physical properties of the soils (structure, bulk density, field capacity) are not the factors that limit the high efficiency, nitrogen and phosphorus fertilization is required because most of the soils are not rich of nitrogen and

Keywords: Çarşamba plain Physical and chemical soil properties Frequency distribution Maize 


\section{Giriş}

Tahıl (mısır, buğday, arpa, yulaf vb.) üretimi dünyada olduğu gibi Türkiye nüfusunun beslenmesinde de büyük önem taşımaktadır. Tahıllar beslenme maddelerinin temel kaynağı olup, sadece insanın gıda ihtiyacını karşılamakla kalmaz, hayvan beslenmesinde yem ihtiyacını da karşılamaktadır (Yağbasanlar, 1990; Şahin, 2001). Tahıl, aynı zamanda ülkemizin ekonomi bağımsılı̆ı̆ında diğer tarım ürünleriyle karşılaştırıldığında, daha büyük öneme sahiptir. Mısır (Zea mays L.), dünya tahıl ekiliş alanı yönünden buğday ve çeltikten sonra üçüncü sırada yer alan bir bitkidir. FAO'nun verilerine göre; dünya mısır ekiliş alanı $1.84 \mathrm{x}$ $10^{8}$ ha, üretimi yaklaşı $1.04 \times 10^{9}$ ton, verimi ise 561.5 $\mathrm{kg} \mathrm{da}^{-1}$ dır (Anonymous, 2014). Ülkemizde ise misırın ekilis alanı $6.8 \times 10^{5}$ ha, üretimi $6.4 \times 10^{6}$ ton, verimi ise $941 \mathrm{~kg} \mathrm{da}{ }^{-1}$ dır. Karadeniz bölgesinde en önemli tarımsal potansiyele sahip olan Çarşamba Ovası'nda, mısır bitkisinin ekiliş alanı 4038 ha, üretimi 27021 ton, verimi $750 \mathrm{~kg} \mathrm{da}^{-1}$ ' dır (TÜIKK, 2016).

Toprak verimliliğinin arttırılması, sürdürebilirliği, korunması gibi süreçlerin devamlılığı, toprakların fiziksel, kimyasal ve biyolojik özelliklerinin belirlenmesi ve bu özelliklerin yapılacak fiziksel, kültürel ve bitkisel uygulamalarla iyileştirilmesiyle mümkün olabilmektedir (Tümsavaş, 2002). Bu nedenle, araştırmacılar tarafından misır ve diğer bitkilerin yetiştirildiği tarım topraklarının verimlilik düzeylerini belirlemek ve artırmak amacıyla yürütülen çalışmalarda, toprakların fiziksel, kimyasal özellikleri incelenmiş, uygun sınıflandırmalar yapılmıştır (Tümsavaş, 2003; Ekberli ve ark., 2005; Ekberli ve Kerimova, 2005; Tümsavaş ve Aksoy, 2009; Turan ve ark., 2010; Özyazıc1 ve ark., 2013b; Soba ve ark., 2015; Hossain ve ark., 2015; Dengiz ve Ekberli, 2017; Ekberli ve Dengiz, 2017; Martin ve ark., 2017; Lipiec ve Usowicz, 2018). Tarım alanlarında çeşitli toprak işlemleri toprakların fiziksel ve kimyasal özelliklerine önemli düzeyde etki yapmaktadır (Moraes ve Benez, 1996; Turgut, 2000; Gülser ve ark., 2010; Özdemir ve ark., 2014; Gülser, 2016; Gülser ve ark., 2016). Ankara Üniversitesi Ziraat Fakültesi Haymana Araştırma ve Uygulama Çiftliği topraklarının verimlilik durumlarını incelenmesine ait yapılan bir araştırmada, toprakların büyük kısmının ağır bünyeli, hafif alkali, tuzsuz, kireçli ve düşük organik maddeye sahip olduğu; bitki besin elementi sonuçlarına göre ise toprakların toplam $\mathrm{N}$, alınabilir $\mathrm{K}$ ve alınabilir $\mathrm{Zn}$ ve $\mathrm{Cu}$ bakımından yeterli olduğu, diğer taraftan alınabilir P, Fe ve Mn ile çözünebilir B bakımından yetersiz olduğu belirlenmiştir (Soba ve ark., 2015). Tümsavaş ve Aksoy (2009), Bursa İli Kahverengi Orman Büyük Toprak Grubu topraklarının verimlilik durumunu belirlemek amaciyla yaptıkları bir araştırmada, araştırma alanını temsil edebilecek şekilde 28 adet toprak örneği alarak, bu örneklerin bazı fiziksel ve kimyasal özelliklerini belirlemişlerdir. Alüviyal büyük toprak grubu tarım topaklarının verimlilik durumlarının belirlenmesi ve potansiyel beslenme sorunlarının saptanmasi amaciyla 30 adet toprak örneğinin alındığı bir araştırmada, toprakların bazı fiziksel ve kimyasal özellikleri belirlenmiştir. Çoğunlukla orta bünyeli, hafif alkali reaksiyonlu, az ve orta düzeyde kireç içeren toprakların \% 43.39'unda organik madde, $\% 46.66$ 'sinda azot, $\% 10$ 'unda fosfor ve $\% 20$ 'sinde kükürt, $\%$ 43.34'ünde çinko ve $\%$ 90'ında mangan bakımından yetersiz olduğu bildirilmiştir (Turan ve ark., 2010). Ateş ve Turan (2015) tarafından, Bingöl ili Merkez ilçesindeki tarım topraklarının bazı toprak özellikleri ve verimlilik düzeylerini belirlemek amacıyla yapılan bir çalışmada, tarım topraklarının; genelde killi-tın bünyeli ve nötr veya nötre yakın reaksiyonlu olduğu, tuzluluk problemi bulunmayan toprakların kireç içeriğinin az kireçli ile orta kireçli arasında değiştiği, organik madde miktarının ise düşük düzeyde olduğu, toprakların büyük çoğunluğunun alınabilir fosfor bakımından yetersiz, alınabilir potasyum bakımından ise yeterli olduğu saptanmıştır. Çanakkale ili Lapseki ilçesi tarım topraklarında yürütülen bir başka çalışmada da; bölge topraklarının yüksek miktarda kireç içerdiği; alkalin reaksiyonlu olan toprakların, organik madde ve alınabilir $\mathrm{P}$ içeriklerinin az, potasyum bakımından zengin düzeyde olduğu; incelenen toprak örneklerinin \% 70 'inde alınabilir $\mathrm{Zn}$ ve $\mathrm{Fe}$ içeriklerinin, \% 55'inde ise Mn içeriğinin az, \% 95'inde de alınabilir $\mathrm{Cu}$ miktarının yeterli seviyede olduğu bildirilmiştir (Demirer ve ark., 2003). Genel olarak, tahıl bitkileri yetiştirilen toprakların fiziksel-kimyasal özelliklerinin optimum düzeyde olmasına yönelik tarımsal yöntemlerin belirlenmesinde, fiziksel-kimyasal özelliklerin degerlendirilmesi gerekir (Schoenholtz ve ark., 2000; Dordas, 2006; Özyazıcı ve ark., 2013a; Kamau ve ark., 2019).

$\mathrm{Bu}$ araştırmanın amacı, Çarşamba Ovası'nda geleneksel toprak işleme yöntemleriyle ana ürün olarak mısır yetiştiriciliği yapılan tarım topraklarının bazı fiziksel ve kimyasal özelliklerinin incelenmesidir.

\section{Materyal ve Yöntem}

Çarşamba Ovası, Samsun ilinin doğusunda Canik dağları ile Karadeniz arasında Yeşilırmak'ın oluşturduğu delta ovasıdır. Ova 0-50 m kotları arasında, 103766 hektarlık alanı kapsamaktadır. Çarşamba Ovası doğu-batı istikametinde $65 \mathrm{~km}$, güney-kuzey istikametinde ise $35 \mathrm{~km}$ uzunluğa sahiptir. Ova taban arazilerinin genel eğimleri güney-kuzey istikametinde olup ortalama \% 0.1'dir. Bu eğim, deniz kenarına yaklaştıkça \% 0-0.02'ye kadar düşmektedir. Yamaç arazilerde ise eğim, \% 2-40 arasında değişmektedir (Anonim, 1984; Anonim, 2012). Ova, bitki örtüsü yönünden çok zengin olup, 58.921 hektar tarım arazisine sahiptir. Ova toprakları alüvyal ve kısmen de 
kolüvyal (kestane rengi topraklar, gri-kestane podzolik topraklar, kahverengi orman toprakları) karakterdedir. Ovada yıllık toplam yağış miktarı $985.9 \mathrm{~mm}$ olup, yıllık sicaklık ortalaması ise $15-17^{\circ} \mathrm{C}$ 'dir.

Araştırma 2013-2014 yıllarında Samsun ili Çarşamba Ovası'nı temsil eden 20 köyde çiftçiler tarafindan geleneksel toprak işleme yöntemleri ile mısır tarımı

yapılan arazilerde gerçekleştirilmiştir. Toprak örneklerinin alındığı lokasyonlar Şekil 1'de gösterilmiştir. Toprak tekstürü hidrometre yöntemiyle (Demiralay, 1993); hacim ağırlığı Demiralay (1993)'a

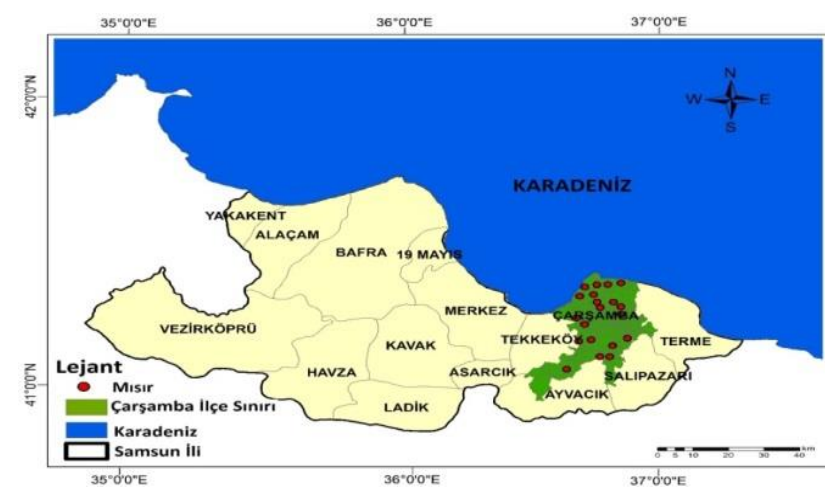

göre;toprak reaksiyonu $(\mathrm{pH})$ 1:1 oranında hazırlanan toprak-su süspansiyonunda ve cam elektrotlu $\mathrm{pH}$ metre ile belirlenmiştir (Bayrakl1, 1987). Elektriksel iletkenlik (EC) $1: 1$ oranında hazırlanan toprak-su süspansiyonunda elektriksel kondaktivite aleti ile (Richards, 1954); kireç $\left(\mathrm{CaCO}_{3}\right) \quad$ Scheibler kalsimetresiyle volümetrik olarak; organik madde Walkley-Black'e göre organik karbonun oksidasyonuyla; azot içeriği ise Kjeldahl yaş yakma yöntemine göre belirlenmiştir (Kacar, 1994).

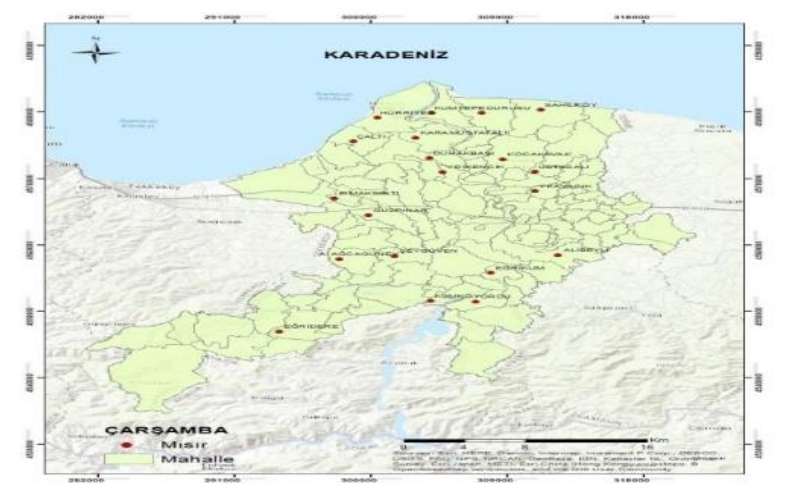

Şekil 1. Toprak örneklerinin alındığı lokasyonlar

Yarayışlı P içeriği, mavi renk yöntemine göre (Olsen ve ark., 1954); değişebilir $\mathrm{K}$ ve $\mathrm{Na}$, toprak örneğinin 1 $\mathrm{N}$ amonyum asetat $(\mathrm{pH}=7.0)$ çözeltisi ile ekstrakte edilmesiyle, $\mathrm{Ca}$ ve $\mathrm{Mg}$ 0.01M EDTA ile titre edilerek (Sağlam, 1997); katyon değişim kapasitesi, Bower yöntemine göre (United States Salinity Laboratory Staff, 1954); alınabilir $\mathrm{Fe}, \mathrm{Cu}, \mathrm{Mn}$ ve $\mathrm{Zn}$ içerikleri (0.005 M DTPA + 0.01 M CaCI2 +0.1 M TEA, pH=7.3) ise Lindsay ve Norvell (1978) tarafından bildirildiği şekli ile belirlenmiştir. Tarla kapasitesi (TK) ve solma noktası (SN) değeri, basınçlı tabla aletinde $1 / 3$ atm ve 15 atm basınç altında toprak örneklerinin hidrolik denge durumuna gelmesinden sonra ağırlık esasına göre (Black, 1965); bitkiye yarayışılı su miktarı (BYS), tarla kapasitesi ve solma noktası arasındaki farktan belirlenmiştir. Toprak analiz sonuçlarına ait tanımlayıcı istatistikler SPSS 17.0 paket programında hesaplanmıştır.

\section{Bulgular ve Tartışma}

\subsection{Misır tarımı yapılan toprakların fiziksel özelliklerinin değişimi}

Geleneksel toprak işleme ile mısır bitkisi yetiştirilen toprakların bazı fiziksel özelliklerine ait tanımlayıcı istatistikler Çizelge 1'de verilmiştir.

Çizelge 1'den görüldüğü gibi; toprakların kil miktarı \% 3.54-64.70 arasında değişmekte olup, ortalama değeri ise \% 40.70'dir. Standart sapma 15.97; varyasyon katsayısı \% 39.23; çarpıklık katsayısı ise -0.447 olarak saptanmıştır.

. Çizelge 1. Mısır bitkisi yetiştirilen toprakların bazı fiziksel

\begin{tabular}{lllllll}
\hline Özellikler & En düşük & En yüksek & Ortalama & St. Sapma & VK, \% & Çarpıklık \\
\hline Kil, \% & 3.54 & 64.70 & 40.70 & 15.97 & 39.23 & -0.447 \\
Silt, \% & 1.30 & 49.75 & 34.20 & 10.14 & 2.96 & -1.057 \\
Kum, \% & 8.77 & 95.17 & 25.09 & 16.98 & 67.67 & 2.769 \\
Db, g cm ${ }^{-3}$ & 1.02 & 1.51 & 1.27 & 0.12 & 9.44 & 0.186 \\
TK, \% & 9.38 & 50.68 & 33.02 & 9.49 & 28.74 & -0.594 \\
SN, \% & 2.79 & 28.24 & 16.03 & 6.29 & 39.23 & -0.159 \\
BYS, \% & 6.59 & 23.34 & 16.99 & 4.04 & 23.77 & -0.896 \\
\hline
\end{tabular}

özelliklerine ait bazı tanımlayıcı istatistikler $(\mathrm{n}=40)$ 
Toprakların silt miktarı \% $1.30-49.75$ arasında değişmekte, ortalama miktarı \% 34.20'dir. Standart sapma, varyasyon katsayısı ve çarpıklı katsayısı parametreleri sirasiyla $10.14 ; \% 2.96 ;-1.057$ olarak bulunmuştur. Toprakların kum miktarı \% 8.77-95.17 arasında değişmekte olup, ortalama miktarı \%25.09 olarak bulunmuştur. Standart sapma, varyasyon katsayısı, çarpıklık sırasıyla $16.98 ; \% 67.67 ; 2.769$ olarak belirlenmiştir. Misır yetiştirilen toprakların bünyesi killi tın, killi, tınlı, kumlu, siltli kil ve siltli killi tın olarak saptanmıştır. Toprakların en düşük hacim ağırlığı $1.02 \mathrm{~g} \mathrm{~cm}^{-3}$, en yüksek hacim ağırlığ1 ise $1.51 \mathrm{~g} \mathrm{~cm}^{-3}$ olup, ortalama değeri $1.27 \mathrm{~g} \mathrm{~cm}^{-3}$ olarak belirlenmiştir. Standart sapma 0.12; varyasyon katsayısı $\% 9.44$; çarpıklık katsayısı ise 0.186 olarak saptanmıştır. Toprakların tarla kapasitesi \% 9.38-50.68 arasinda değişmekte olup, ortalama değeri \% 33.02'dir. Standart sapma, varyasyon katsayısı, çarpıklık ölçütü sırasıyla 9.49; \% 28.74; -0.594 olarak belirlenmiştir. Toprakların solma noktası \% 2.79-28.24 arasında değişmekte, olup, ortalama olarak \% 16.03 bulunmuştur. Standart sapma 6.29; varyasyon katsayısı \% 39.23; çarpıklık ölçütü ise -0.159 olarak saptanmıştır.

Toprakların bitkiye yarayışlı su miktarı \% 6.5923.34 arasında değişmekte, ortalama ise \% 16.99'dur. İstatistiksel göstericiler sirasıyla 4.04; \% 23.77; -0.896 olarak belirlenmiştir.

Toprakların kil içeriği ile hacim ağırlığ önemli negatif $\left(-0.424^{*}\right)$ ilişkiler belirlenmiştir. Hacim ağırlığı ve kum miktarı arasında önemli pozitif $\left(0.447^{*}\right)$; kum içeriği ve BYS arasında ise önemli negatif $(-0.410 *)$ ilişki bulunmuştur. Toprakların TK değeri ile SN'sı ve BYS değerleri arasında çok önemli pozitif (sırasıyla $0.949^{* *}$ ve $0.871^{* *}$ ) ilişkiler saptanmıştır. Ayrıca toprakların SN değeri BYS değeri ile çok önemli pozitif $\left(0.671^{* *}\right)$ ilişki göstermiştir. Toprakların bazı fiziksel ve kimyasal özelliklerine ait tanımlayıcı istatistiklerden görüldüğü gibi, elde edilen değerler geçerllik sınırları dahilinde olmaktadır. Toprakların hacim ağırlığı, kil ve tarla kapasitesi değerlerine ait frekans dağılımları Şekil 2, Şekil 3 ve Şekil 4'de verilmiştir.

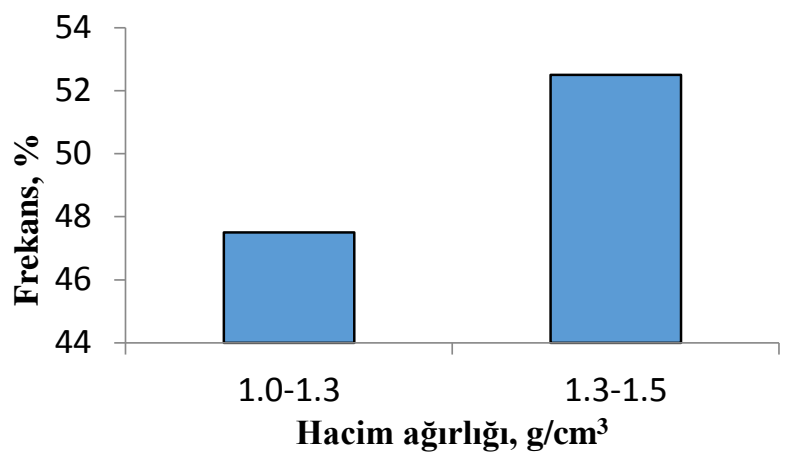

Şekil 2. Toprakların hacim ağırlı̆̆ dağılımı $(\mathrm{n}=40)$

Şekil 2'de görüldüğü gibi, misır yetiştirilen toprakların hacim ağırlığı değerlerinin \% 47.5'i 1.0-1.3 $\mathrm{g} \mathrm{cm}$; \% 52.5'i ise 1.3-1.5 $\mathrm{g} \mathrm{cm}^{-3}$ aralı̆̆ında değişmektedir. Hacim ağırlığı; toprak nemi, prozite, hidrolik iletkenlik gibi toprak özellikleriyle ilişkili olup, toprak kalitesinin bir ölçütü olmaktadır (Dam ve ark., 2005). Hacim ağırlığının $1.5-1.6 \mathrm{~g} \mathrm{~cm}^{-3}$ degerlerinden yüksek olması durumunda, bitki kök büyümesinin engellenebileceği bildirilmiştir (Raper ve ark., 1993).

Çizelge 2. Mısır bitkisi yetiştirilen toprakların bazı kimyasal özelliklerine ait bazı tanımlayıcı istatistikler ( $\mathrm{n}=40)$

\begin{tabular}{lllllll}
\hline \hline Özellikler & En düşük & En yüksek & Ortalama & St. Sapma & VK, & Çarpıklık \\
\hline $\mathrm{pH},(1: 1)$ & 5.32 & 7.97 & 7.55 & 0.66 & 8.74 & -2.737 \\
$\mathrm{EC}, \mathrm{dS} \mathrm{m}^{-1}(1: 1)$ & 0.21 & 0.68 & 0.49 & 0.11 & 22.44 & -0.652 \\
$\mathrm{CaCO}_{3}, \%$ & 0.47 & 7.04 & 2.62 & 1.60 & 0.61 & 1.530 \\
$\mathrm{OM} \%$ & 0.81 & 4.16 & 2.05 & 0.75 & 36.58 & 1.250 \\
$\mathrm{~N}, \%$ & 0.06 & 0.21 & 0.13 & 0.03 & 23.07 & 0.353 \\
$\mathrm{P}, \mathrm{ppm}$ & 0.02 & 75.09 & 17.14 & 20.87 & 121.7 & 1.532 \\
$\mathrm{~K}, \mathrm{cmol} \mathrm{kg}$ & 0.23 & 1.99 & 0.59 & 0.40 & 67.79 & 2.045 \\
$\mathrm{Ca}+\mathrm{Mg}^{-1} \mathrm{cmol} \mathrm{kg}^{-1}$ & 6.86 & 76.98 & 38.79 & 14.45 & 37.25 & 0.503 \\
$\mathrm{Na}, \mathrm{cmol} \mathrm{kg}$ & 0.32 & 2.33 & 1.13 & 0.77 & 68.14 & 0.365 \\
$\mathrm{KDK}, \mathrm{cmol} \mathrm{kg}$ & 7.79 & 79.35 & 40.52 & 14.73 & 36.35 & 0.505 \\
$\mathrm{Fe}, \mathrm{ppm}$ & 9.58 & 69.12 & 29.97 & 14.48 & 48.31 & 1.106 \\
$\mathrm{Mn}, \mathrm{ppm}$ & 5.68 & 158.45 & 20.98 & 36.20 & 172.5 & 3.327 \\
$\mathrm{Cu}, \mathrm{ppm}$ & 0.69 & 7.36 & 4.57 & 1.36 & 29.75 & -0.577 \\
$\mathrm{Zn}, \mathrm{ppm}$ & 0.31 & 4.50 & 0.83 & 0.88 & 106.0 & 3.327 \\
\hline
\end{tabular}

pH: Toprak reaksiyonu; EC: Elektriksel iletkenlik; CaCO3: Kireç; OM: Organik madde; N: Azot; P: Fosfor; K: Potasyum; Ca+Mg: Kalsiyum+Magnezyum; Na: Sodyum; KDK: Katyon değişim kapasitesi; Fe: Demir; Mn: Mangan; Cu: Bakır; Zn: Çinko; VK: Varyasyon katsayıs1. 
Toprakların çoğunluğu killi ve killi tın bünyeye sahip olup, genel olarak topraklarda kil miktarı fazla olmamaktadır (Şekil 3).

Ekberli ve ark. (2005), iklim faktörlerinin ve farklı azot dozlarının misır bitkisinin verim ve azot kapsamına etkisini araştırdıkları bir çalışmada; 7 farklı lokasyonda toprakların kil miktarının \% 7.98 ile \% 63.01 arasında değiştiğini ve toprakların çoğunluğunun kil bünyeye sahip olduğunu bildirmişlerdir. Genel olarak, mısır bitkisi en iyi gelişimi ve yüksek verimi, organik madde ve bitki besin maddelerince zengin, drenaji ve havalanması iyi olan derin ișlenmiş, sıcak, tın bünyeli topraklarda göstermektedir (Emeklier, 1997).

Şekil 4'te görüldüğü gibi, misır yetiştirilen toprakların \% 5'inde tarla kapasitesi \% 10'dan küçük; $\% 35$ 'inde $\% 10$ ile $\% 30$; \% 60' 'n da ise $\% 30$ ile $\% 50$ arasında değişmiştir.

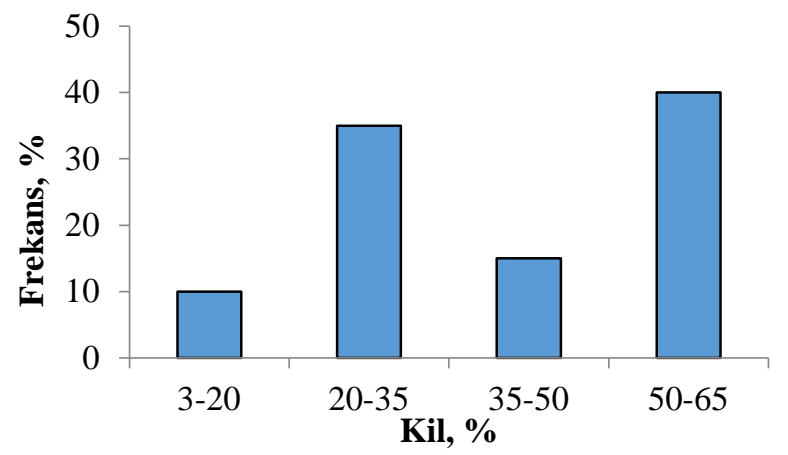

Şekil 3. Mısır bitkisi yetiştirilen topraklarda kil miktarının dağılımı $(\mathrm{n}=40)$

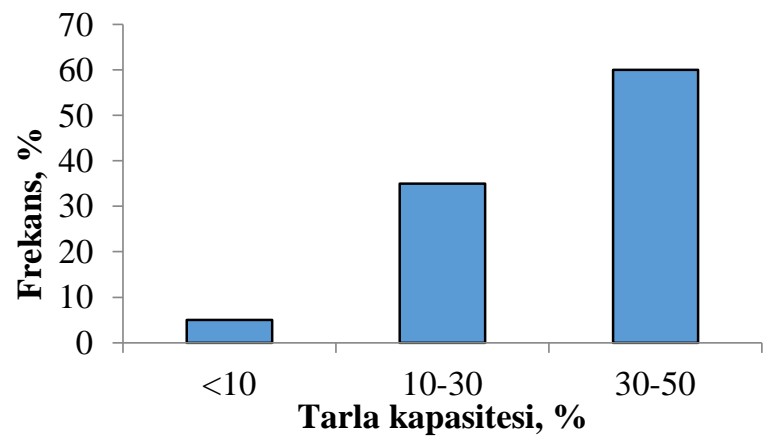

Şekil 4. Mısır bitkisi yetiştirilen topraklarda tarla kapasitesinin dağılımı $(\mathrm{n}=40)$

Tarla kapasitesi değerleri yüksek verim elde edilmesine imkan veren sınırlar dahilinde olmaktadır (Yildırım ve Kodal, 1995; Biber ve Tekin, 2006). Sağlam (2013), çok değişkenli istatistiksel yöntemler ile toprak özelliklerinin gruplandırılması üzerine yaptığı bir çalışmada, toprakların tarla kapasitelerinin \% 30.25 ile $\% 43.41$ arasında değiştiğini ve ortalama tarla kapasitesinin ise \% 35.90 olduğunu belirtmiștir. Braunworth ve Mack (1989), su eksikliğinin mısır verimi ve kalitesine etkisini araştırarak, kullanılabilir su tutma kapasitesinin \% 50'si tüketilmeden yapılan sulama koşullarında, verim değerinin birbirine yakın olduğunu belirlemişlerdir.

\subsection{Misır tarımı yapılan toprakların kimyasal özelliklerinin değişimi}

Geleneksel yöntemler ile misır bitkisi yetiştirilen toprakların bazı kimyasal özelliklerine ait tanımlayıcı istatistikler Çizelge 2'de verilmiştir.

Çizelge 2'den görüldüğü gibi, araştırma toprakları çoğunlukla nötr ve hafif alkalin reaksiyona sahip olup, ortalama $\mathrm{pH}$ değeri 7.55 olmaktadır. Standart sapma 0.66 ; varyasyon katsayısı $\% 8.74$; çarpıklık katsayısı ise -2.737 olarak saptanmıştır. Araştırma toprakları çoğunlukla tuzsuz olup, ortalama EC miktarı $0.49 \mathrm{dS} \mathrm{m}^{-1}$ dir. Standart sapma, varyasyon katsayıs1, çarpıklık parametreleri sırasıly $0.11 ; \% 22.44 ;-0.652$ olarak belirlenmiştir. Topraklar kireç içeriği bakımından çoğunlukla az kireçli olup, ortalama değeri \% 2.62'dir. Uygun istatistiksel parametreler ise sirasiyla $1.60 ; \%$ $0.61 ; 1.530$ olarak bulunmuştur. Toprakların organik madde miktarı genellikle düşük (\% 1.0-2.0) ve orta (\% 2.0-3.0) düzeyde değişmekte, ortalama miktarı ise \% 2.05 'dir. Standart sapma 0.75 ; varyasyon katsayis $\%$ 36.58; çarpıklık ise -1.250 olarak saptanmıştır. Topraklar azot bakımından çoğunlukla düşük düzeyde olup, ortalama azot miktarı \% 0.13 bulunmuştur. Standart sapma, varyasyon katsayısı, çarpıklık katsayısı sirasıyla 0.03 ; \% 23.07; 0.353 olarak belirlenmiştir. Toprakların fosfor miktarı en düşük $0.02 \mathrm{ppm}$, en yüksek ise $75.09 \mathrm{ppm}$ olarak saptanmıştır. Ortalama fosfor miktarı $17.14 \mathrm{ppm}$ olup, toprakların fosfor kapsamı çoğunlukla az ve orta düzeydedir. İstatistiksel göstericiler sirasiyla 20.87; \% 121.76; 1.532 olarak belirlenmiştir. Topraklar potasyum bakımından genellikle orta düzeyde olup, ortalama potasyum değeri $0.59 \mathrm{cmol} \mathrm{kg}^{-1}$ dir. Standart sapma 0.40 ; varyasyon katsayısı \% 67.79; çarpıklık katsayısı ise 2.045 olarak saptanmıştır. Topraklarda $\mathrm{Ca}+\mathrm{Mg}$ miktarı 6.86-76.98 cmol kg-1 arasında değişmekte olup, ortalama değer $38.79 \mathrm{cmol} \mathrm{kg}^{-1}$ dir. Standart sapma, varyasyon katsayısı, çarpıklık katsayısı ise sırasıyla 14.45; \% 37.25; 0.503 olarak belirlenmiş̧ir. Toprakların sodyum kapsamı orta, yüksek ve çok yüksek seviye arasında değişmekte olup, ortalama $1.13 \mathrm{cmol} \mathrm{kg}^{-1}$ dır. Standart sapma, varyasyon katsayısı ve çarpıklık sırasıly 0.77 ; $\%$ 68.14; 0.365 olarak bulunmuştur. Topraklardaki KDK seviyesi çoğunlukla yüksek ve çok yüksek arasında olup, ortalama KDK değeri $40.52 \mathrm{cmol} \mathrm{kg}^{-1}$ dır. Standart sapma 14.73; varyasyon katsayıs1 \% 36.35; çarpıklık katsayısı ise 0.505 olarak saptanmıştır. Toprakların demir kapsamı çoğunlukla orta ve yüksek arasında değişmekte olup, ortalama demir miktarı 29.97 ppm'dir. İstatistiksel parametreler sirasiyla 14.48; $\%$ 48.31; 1.106 olarak bulunmuştur. Toprakların mangan kapsamları genellikle düşük olup, ortalama 20.98 ppm' dir. Standart sapma, varyasyon ve çarpıklık katsayıs1 sirasıly $36.20 ; \% 172.54 ; 3.327$ olarak 
belirlenmiştir. Toprakların bakır miktarı çok yüksek düzeyde olup, ortalama miktarı 4.57 ppm'dir. Standart sapma 1.36; varyasyon katsayısı \% 29.75; çarpıklık katsayısı ise -0.577 olarak saptanmıştır. Toprakların çinko kapsamı çoğunlukla çok düşük ve orta düzeyde değişmekte, ortalama çinko kapsamı 0.83 ppm'dir. İstatistiksel göstericiler sırasıly $0.88 ; \% 106.02 ; 3.327$ olarak bulunmuştur. Düzensiz tarımsal uygulamalar (gübreleme, sulama vb.), toprakların farklı fizikokimyasal özellikleri, bazı toprak özelliklerinin (P, Mn, $\mathrm{Zn)}$ geniş aralıkta değişimine, dolayısıyla değerlerin homojen olmayan dağılımına ve varyasyon katsayılarının yüksek olmasına sebep olabilir.

Toprakların $\mathrm{pH}$ değeriyle $\mathrm{Fe}$ ve $\mathrm{Mn}$ değerleri arasında çok önemli negatif (sırasıyla $-0.660 * *$ ve $0.958^{* *}$ ) ilişkiler belirlenmiştir. Toprakların EC değeriyle $\mathrm{OM}, \mathrm{N}, \mathrm{K}, \mathrm{Ca}+\mathrm{Mg}, \mathrm{KDK}$ ve $\mathrm{Cu}$ arasındaki korelasyon ilişkiler, sırasıyla $0.438^{*} ; 0.476^{*} ; 0.395^{*}$; $0.412^{*} ; 0.425^{*}$ ve $0.651^{* *}$ olarak saptanmıştır. Topraklardaki $\mathrm{CaCO}_{3}$ kapsamıyla $\mathrm{Na}$ miktarı arasında çok önemli pozitif $\left(0.533^{* *}\right)$, Cu miktarıyla ise önemli pozitif $(0.464 *)$ ilişkiler elde edilmiştir. Toprakların OM miktarı; N, K, Ca+Mg, Na, KDK ve Cu miktarları ile çok önemli, P miktarı ile önemli pozitif ilişkiler göstermiştir. Topraklardaki $\mathrm{N}$ içeriği; $\mathrm{K}$ ve $\mathrm{Cu}$ içerikleriyle çok önemli, Zn içeriği ile önemli pozitif ilişkiler vermiştir. Toprakların $\mathrm{P}$ miktarı ile $\mathrm{K}$ ve $\mathrm{Zn}$ miktarları arasında çok önemli pozitif ilişkiler saptanmıştır. Toprakların K miktarıyla; Fe miktarı arasında önemli negatif, $\mathrm{Cu}$ miktarı ile önemli pozitif, $\mathrm{Zn}$ miktarıla ise çok önemli pozitif ilişkiler bulunmuştur. Toprakların KDK kapsamı ile $\mathrm{Cu}$ arasında önemli pozitif ilişki belirlenmiştir. Fe içeriği $\mathrm{Mn}$ içeriğiyle çok önemli pozitif ilişki göstermiştir.

Toprakların $\mathrm{pH}, \mathrm{EC}, \mathrm{OM}, \mathrm{N}, \mathrm{P}, \mathrm{K}$ ve KDK miktarlarına ait frekans dağılımları Şekil 5-11'de gösterilmiştir. Şekil 5'ten görüldüğü gibi, araştırma topraklarının \% 5'i kuvvetli asit, \% 2.5'i orta ve hafif asitli, \% $15^{\prime} \mathrm{i}$ nötr, $\% 77.5^{\prime} \mathrm{i}$ ise hafif alkalin reaksiyonludur.

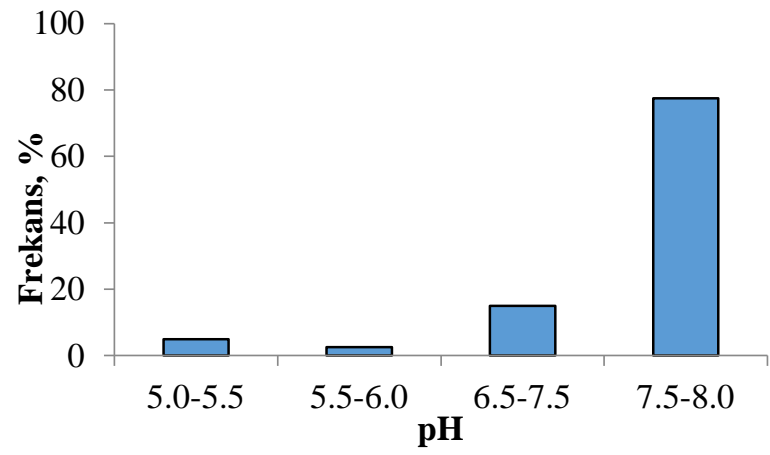

Şekil 5. Mısır bitkisi yetiştirilen topraklarda $\mathrm{pH}$ değerlerinin dağılımı $(n=40)$

Soba ve ark. (2015) tarafindan, Ankara Üniversitesi Ziraat Fakültesi Haymana Araştırma ve Uygulama Çiftliği topraklarının verimlilik durumlarının değerlendirildiği bir çalışmada; çiftlik topraklarının \% 10.8'inde $\mathrm{pH}$ değerleri 8.5-8.7; \% 89.2'sinde ise 7.5-8.5 arasinda bulunmuştur.

Araştırma topraklarının elektriksel iletkenlik değerlerinin \% 25'i $0.2-0.4 \mathrm{dS} \mathrm{m}^{-1}$; \% 52.5'i 0.4-0.6 $\mathrm{dS} \mathrm{m}{ }^{-1}$ ve \% 22.5' $\mathrm{i}$ ise $0.6-0.8 \mathrm{dS} \mathrm{m}^{-1}$ arasında olduğu belirlenmiştir (Şekil 6).

Topraklarda tuzluluğun önemli bir göstergesi olan EC değerlerinden görüldüğü gibi, araştırma topraklarında tuzluluk problemi olmamaktadır. Tümsavaş (2002), Bursa ili kolüvyal büyük toprak grubunun verimlilik durumunu belirlediği bir çalışmasında; araştırma topraklarının elektriksel iletkenlik değerlerinin $0.26 \mathrm{dS} \mathrm{m}^{-1}$ ile $1.62 \mathrm{dS} \mathrm{m}^{-1}$ arasında değiştiğini, toprakların tuzluluk yönünden herhangi bir sorunu bulunmadığını bildirmiştir.

Organik madde miktarı, mısır bitkisi yetiştirilen toprakların \% 5'inde çok az $(<\% 1)$; \% 47.5'inde az $\left(\begin{array}{ll}\% & 1-2\end{array}\right) ; \%$ 37.5'inde orta ( $\%$ 2-3); \% 5 'inde iyi $\left(\begin{array}{ll}\% & 3-4\end{array}\right) ; \%$ 5'inde ise yüksek ( $>\%$ 4) olarak belirlenmiştir (Şekil 7). Şekilde görüldüğü gibi, mısır bitkisi yetiştirilen topraklar, organik madde bakımından zengin değildir.

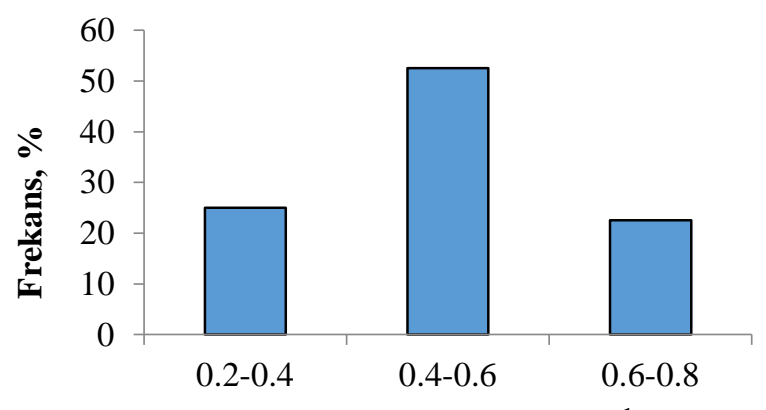

Elektriksel iletkenlik, dS m ${ }^{-1}$

Şekil 6. Mısır bitkisi yetiştirilen topraklarda elektriksel iletkenlik degerlerinin dağ $11 ı \mathrm{~m} 1(n=40)$

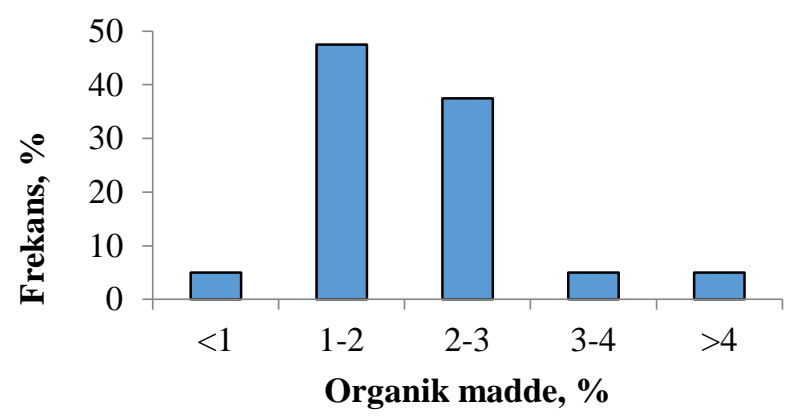

Şekil 7. Mısır bitkisi yetiştirilen topraklarda organik madde miktarının dağılımı $(\mathrm{n}=40)$

Ateş ve Turan (2015), Bingöl ili tarım topraklarının bazı özellikleri ve verimlilik düzeylerini araştırdıkları bir çalışmada, tarım topraklarının organik madde kapsamlarının \% 0.03 ile \% 7.34 arasında değiştiğini ve toprakların büyük çoğunluğunun çok az, az ve orta düzeyde organik madde içerdiğini saptamışlardır. 
Şekil 8'de görüldüğü gibi, mısır bitkisi yetiştirilen araştırma topraklarının \% 65'inde azot miktarı düşük (\% 0.05-0.15), \% 30'unda orta (\% $0.15-0.25)$ ve $\%$ 5'inde ise fazla (\% $0.25-0.50)$ düzeydedir. Dolayısıyla, mısır bitkisi yetiştirilen araştırma topraklarının azot kapsamı, çoğunlukla düşük düzeyde yer almaktadır. Tarım yapılan toprakların bazı fiziksel ve kimyasal özelliklerini incelemek ve bitki besleme ile ilgili sorunlarını belirlemek amacıyla yürütülmüş bir çalışmada, toprakların toplam azot kapsamının \% 0.048 ile \% 0.488 arasında değiştiği, toplam azot kapsamının incelenen toprak örneklerinin \% 3.85 'inde az, \% 23.08 'inde yeterli, $\% 57.69$ 'unda fazla ve $\% 15.38$ 'inde ise çok fazla düzeyde olduğu belirlenmiştir (Özyazıcı ve ark., 2013b).

Geleneksel toprak işleme yapılan tarlalarda az $(<6$ ppm), orta (6-14 ppm), iyi (14-26 ppm), yüksek (26-38 ppm) ve çok yüksek (> $38 \mathrm{ppm})$ fosfor miktarları, araştırma alanının sırasıyla $\% 45 ; \% 20 ; \% 7.5 ; \% 10$ ve $\% 17.5$ kısmını oluşturmaktadır (Şekil 9). Araştırma toprakları fosfor bakımından yeterli düzeyde değildir.

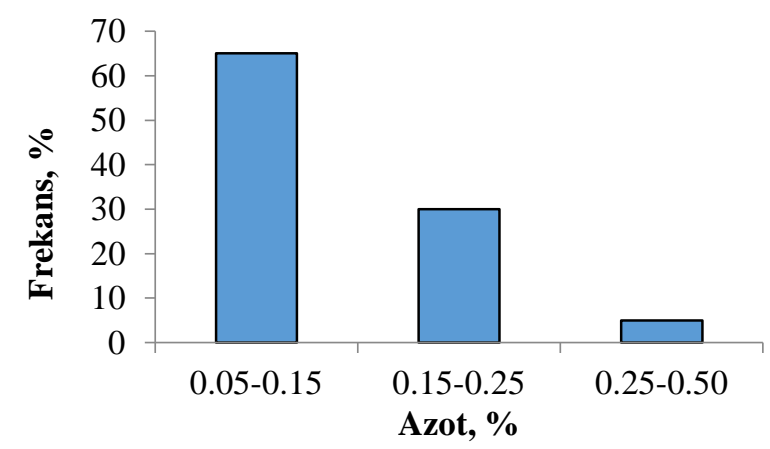

Şekil 8. Mısır bitkisi yetiştirilen topraklarda azot miktarının dağılımı $(\mathrm{n}=40)$

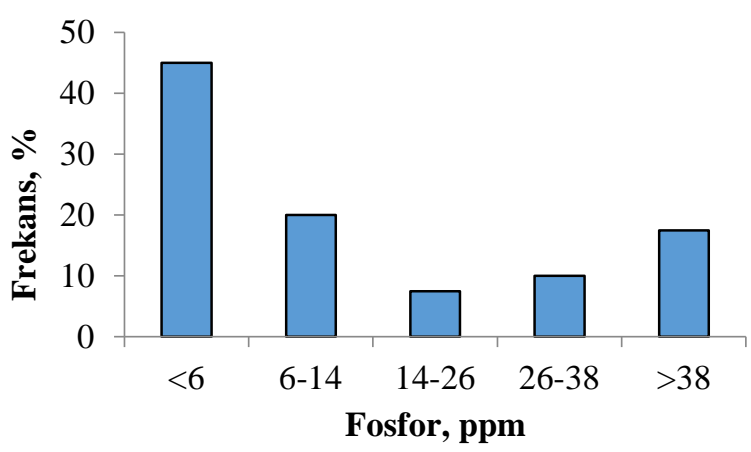

Şekil 9. Mısır bitkisi yetiştirilen topraklarda fosfor miktarının dağılımı $(\mathrm{n}=40)$

Zengin ve Şeker (2003), Konya iline bağlı Beyşehir ilçesi tarım topraklarının verimlilik durumlarını belirlemek amacı ile yaptıkları bir çalışmada; toplam 48 örneğin yarayışlı fosfor içeriklerinin $3.50 \mathrm{ppm}$ ile 126.14 ppm arasında değiştiğini ve ortalama 24.48 ppm olduğunu saptamışlardır. Ayrıca araştırmacılar, toprakların fosfor içeriğinin yüksek düzeyde olduğunu bildirmişlerdir.

Şekil 10'da görüldüğü gibi, araştırma topraklarının $\% 25$ 'inde potasyum miktarı düşük $\left(0.2-0.3 \mathrm{cmol} \mathrm{kg}^{-1}\right)$; $\% 47.5$ 'inde orta $\left(0.3-0.7 \mathrm{cmol} \mathrm{kg}^{-1}\right)$; \%25'inde yüksek $\left(0.7-2.0 \mathrm{cmol} \mathrm{kg}^{-1}\right) ; \% 2.5$ 'inde ise çok yüksek $\left(>2 \mathrm{cmol} \mathrm{kg}^{-1}\right.$ ) olarak belirlenmişir. Ortalama potasyum miktarı $0.59 \mathrm{cmol} \mathrm{kg}^{-1}$ olup (Çizelge 2), genel olarak araştırma topraklarında potasyum kapsamı orta düzeydedir.

Bursa ili alüvyal tarım topaklarının verimlilik durumlarının ortaya konması ve potansiyel beslenme sorunlarını saptamak amacıyla, yürütülen bir araştırmada değerlendirilen 30 adet toprak örneğinde, toprakların \% 6.67'sinin az, \% 70'nin yeterli ve \% 23.33'nün fazla seviyede potasyum içerdiği ve bu sonuçlara göre tarım topraklarının potasyum yönünden yeterli oldukları belirlenmiştir (Turan ve ark., 2010).

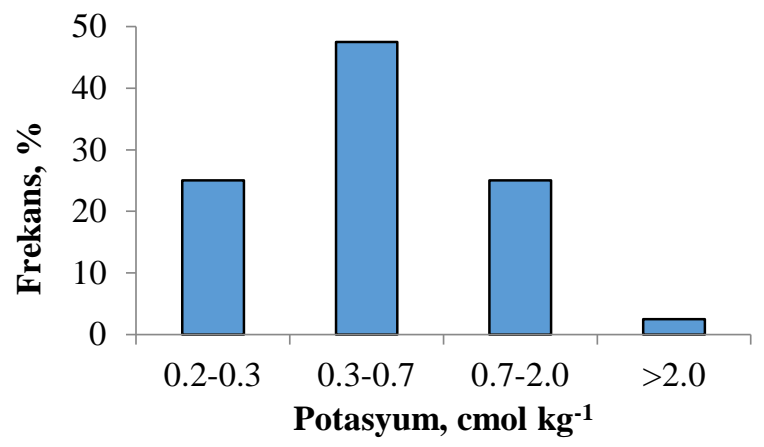

Şekil 10. Mısır bitkisi yetiştirilen topraklarda potasyum miktarının dağılımı $(\mathrm{n}=40)$

Geleneksel işleme yapılan topraklarda ortalama KDK değeri $40.52 \mathrm{cmol} \mathrm{kg}^{-1}$ (Çizelge 2) olup; düşük (6$\left.12 \mathrm{cmol} \mathrm{kg}^{-1}\right)$, orta $\left(12-25 \mathrm{cmol} \mathrm{kg}^{-1}\right)$, yüksek $(25-40$ $\left.\mathrm{cmol} \mathrm{kg}^{-1}\right)$, çok yüksek $\left(>40 \mathrm{cmol} \mathrm{kg}^{-1}\right)$ düzeyde KDK miktarları mısır bitkisi yetiştirilen çalışma alanının sırasıyla \% 5; \% 5; \% 40 ve \% 50'sini oluşturmaktadır (Şekil 11). Genel olarak, araştırma topraklarında KDK miktarı yüksektir.

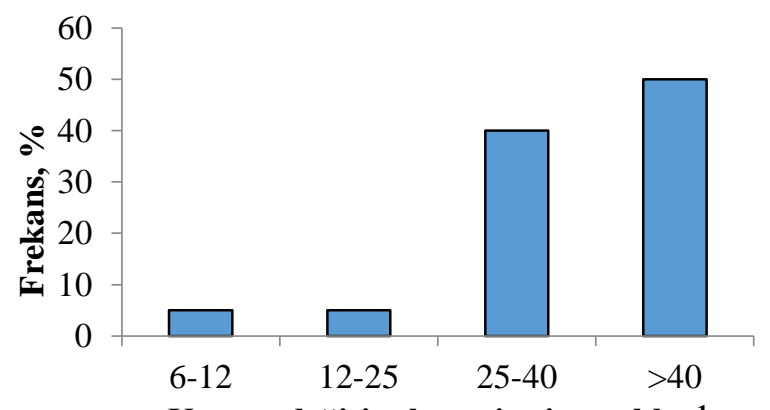

Katyon değişim kapasitesi, $\mathbf{c m o l ~ k g}^{-1}$

Şekil 11. Misır bitkisi yetiştirilen topraklarda katyon değişim kapasitesi değeri dağılımı $(n=40)$

Karaduman ve Çimrin (2016), tarım topraklarının besin elementi durumları ve bunların bazı toprak 
özellikleri ile ilişkilerini belirledikleri bir çalışmada, 53 noktadan alınan toplam 106 örnekte katyon değişim kapasitesinin $14 \mathrm{cmol} \mathrm{kg}^{-1}$ ile $44 \mathrm{cmol} \mathrm{kg}^{-1}$ arasında değiştiğini bildirmişlerdir.

\section{Sonuc}

Çarşamba Ovası'nın geleneksel toprak işleme ile mısır bitkisi yetiştirilen tarım topraklarının bazı fiziksel ve kimyasal özellikleri belirlenmiş; bu özelliklerin frekans dağılımları analiz edilmiştir. Araştırma sonuçlarına göre; mısır bitkisi yetiştirilen tarım arazileri çoğunluğu killi ve killi tınlı bünyeye sahiptir. Toprakların hacim ağırlığ değerleri 1.02-1.51 aralığında belirlenmiştir. Mısır yetiştirilen toprakların \% 60'ında tarla kapasitesi \% 30 ile $\% \quad 50$ arasında değişmektedir. Toprakların solma noktası ve bitkiye yarayışı ı su miktarının ortalama değerleri sırasıyla \% 16.03; \% 16.99 olarak belirlenmiş̧ir. Dolayısıyla, toprakların bünyesi, hacim ağırlığı, tarla kapasitesi gibi fiziksel özellikleri, genel olarak araştırma topraklarından yüksek verim elde edilmesini sinırlandıran faktörler olmamaktadır. Geleneksel toprak işleme ile mısır bitkisi yetiştirilen toprakların \% 77.5'inin hafif alkali reaksiyonlu ve topraklarda tuzluluk probleminin olmaması, araştırma topraklarınnın birçok kültür bitkisinin yetiştirilmesi için uygun olduğunu göstermektedir. Toprakların büyük bir kısmı az kireçli olup; organik madde miktarı ise $\% 47.5$ 'inde çok az ve az, \% 42.5'inde ise orta ve iyi düzeyde belirlenmiştir. Azot miktarı araştırma topraklarının \% 65 'inde düşük, \% 35 'inde ise orta ve fazla düzeyde saptanmıştır. Toprakların çok büyük kısmı fosfor bakımından zengin olmadığından fosforlu gübrelemeye ihtiyaç duyulmaktadır. Araştırma topraklarının potasyum kapsamı çoğunlukla orta düzeydedir. Toprakların katyon değişim kapasitesi genellikle yüksek ve çok yüksektir. Araştırma topraklarının \% 92'sinde demir yüksek, \% 85'inde bakır çok yüksek, \% 87.5'inde mangan çok düşük, \% 72.5 'inde ise çinko çok düşük düzeyde saptanmıştır. Özellikle toprakların çoğunluğunda görülen bakır fazlalığ tehlikesi yaratabilmektedir. Ayrıca araştırma topraklarının çoğunluğunda görülen mangan noksanlığ 1 ovada tarımsal üretimi sınırlayıcı bir faktör olarak ortaya çıkabilir. $\mathrm{Bu}$ araştırma sonuçları ova topraklarında yetiştirilen mısır bitkisinin besin elementi durumunu tam olarak ortaya koyamayacağından, bitkilerin en yüksek verim düzeyine uygun besin elementi isteklerinin detaylı olarak araştırılması ve besin elementlerine ait saptanan noksanlık belirtilerinin giderilmesi için çeşitli tarımsal işlemlerin ve uygun gübreleme programlarının yapılması gerekmektedir.

\section{Kaynaklar}

Anonim, 1984. Samsun ili verimlilik envanteri ve gübre ihtiyacı raporu. Yayın No:23, Genel Yayın No:760, Ankara.

Anonim, 2012. Samsun ili tarım mastır planı. T.C. Samsun İl Özel İdaresi.

Anonymous, 2014. Food and Agriculture Organization of the United Nations. http://www.fao.org/statistics (Erişim Tarihi: 20.04.2017).

Ateş, K., Turan, V., 2015. Bingöl ili merkez ilçesi tarım topraklarının bazı özellikleri ve verimlilik düzeyleri. Türkiye Tarımsal Araştırmalar Dergisi, 2: 108-113.

Bayrakl1, F., 1987. Toprak ve bitki analizleri. Ondokuz Mayıs Üniversitesi Yayınları, No:17, Samsun.

Biber, Ç., Kara T., 2006. Misır bitkisinin bitki su tüketimi ve kısıtlı sulama uygulamaları. Ondokuz Mayıs Üniversitesi Ziraat Fakültesi Dergisi, 21(1): 140-146.

Black, C.A., 1965. Methods of soil analysis Part IPhysical and mineralogical methods, Soil Science Society of America, No: 9, USA.

Braunworth, W.S., Mack, H.J., 1989. The possible use of crop water stres index as an indicator of evapotranspiration deficits and yield reduction in sweet corn. Journal of the American Society for Horticultural Science, 114(4): 542-546.

Dam, R.F., Mehdi, B.B., Burgess, M.S.E., Madramootoo, C.A., Mehuys, G.R., Callum, I.R., 2005. Soil bulk density and crop yield under eleven consecutive years of corn with different tillage and residue practices in a sandy loam soil in central Canada. Soil \& Tillage Research, 84: 41-53.

Demiralay, İ., 1993. Toprak fiziksel analizleri. Atatürk Üniversitesi Ziraat Fakültesi Yayınları No:143, Erzurum.

Demirer, T., Kaleli, Ş., Öztokat Kuzucu, C., 2003. A study to determine fertility status in the ÇanakkaleLapseki agricultural areas, Turkey. Journal of Arid Environments, 54: 485-493.

Dengiz, O., Ekberli, İ., 2017. Bazı vertisol alt grup topraklarının fizikokimyasal ve isısal özelliklerinin incelenmesi. Akademik Ziraat Dergisi, 6 (1): 45-52.

Dordas, C., 2006. Foliar boron application improves seed set, seed yield, and seed quality of alfalfa. Agronomy Journal, 98: 907-913.

Ekberli, İ., Dengiz, O., 2017. Bazalt ana materyali ve farklı topografik pozisyon üzerinde oluşmuş toprakların bazı topografik özellikler ve fizikselkimyasal özellikleri arasındaki doğrusal regresyon modellerinin belirlenmesi. Toprak Su Dergisi, 6(1): 15-27.

Ekberli, İ., Horuz, A., Korkmaz, A., 2005. İklim faktörleri ve farklı azot dozlarının misır bitkisinde verim ve azot kapsamina etkisi. Ondokuz Mayıs Üniversitesi Ziraat Fakültesi Dergisi, 20(1): 12-17.

Ekberli, İ., Kerimova, E., 2005. Azerbaycan'ın Şirvan Bölgesi’nde sulanan killi Bir toprağın bazı fiziksel- 
kimyasal parametrelerinin değişimi. Ondokuz Mayıs Üniversitesi Ziraat Fakültesi Dergisi, 20(3): 54-59.

Emeklier, H.Y., 1997. Erkenci hibrid mısır çesitlerinin verim ve fenotipik özellikleri üzerine arastırmalar. Ankara Üniversitesi Ziraat Fakültesi, Yayın No:1493, Bilimsel araştırma ve incelemeler, 817, Ankara.

Gülser, C., 2016. Changes in soil physical properties with hazelnut husk and tobacco waste applications. VII International Scientific Agriculture Symposium," Agrosym 2016", 6-9 October, Jahorina, Bosnia and Herzegovina. Proceedings, pp. 2032-2036.

Gülser, C., Demir, Z., İç, S., 2010. Changes in some soil properties at different incubation periods after tobacco waste application. Journal of Environmental Biology, 31(5): 671-674.

Gülser, C., Ekberli, İ., Candemir, F., Demir, Z., 2016. Spatial variability of soil physical properties in a cultivated field. Eurasian Journal of Soil Science, 5(3): 192-200.

Hossain, M.F., Chen, W., Zhang, Yu., 2015. Bulk density of mineral and organic soils in the Canada's arctic and sub-arctic. Information Processing in Agriculture, 2: 183-190.

Kacar. B., 1994. Bitki ve Toprağın Kimyasal Analizleri III, Toprak analizleri. Ankara Üniversitesi Ziraat Fakültesi Eğitim Araştırma ve Geliştirme Vakfı Yayınları, No:3, Ankara.

Kamau, J.W., Biber-Freudenberger, L., Lamers, J.P.A., Stellmacher, T., Borgemeister, C., 2019. Soil fertility and biodiversity on organic and conventional smallholder farms in Kenya. Applied Soil Ecology, 134: 85-97.

Karaduman, A., Çimrin, K.M., 2016. Gaziantep yöresi tarım topraklarının besin elementi durumları ve bunların bazı toprak özellikleri ile ilişkileri. Kahramanmaraş Sütçü İmam Üniversitesi Doğa Bilimleri Dergisi, 19(2): 117-129.

Lindsay, L., Norvell, W.A., 1978. Development of a DTPA soil test for zinc, iron, manganese and copper. Soil Science Society of American Proceeding 42: 421-428.

Lipiec, J., Usowicz, B., 2018. Spatial relationships among cereal yields and selected soil physical and chemical properties. Science of the Total Environment 633: 1579-1590.

Martin, M.A., Reyes, M., Taguas, F.J., 2017. Estimating soil bulk density with information metrics of soil texture. Geoderma, 287: 66-70.

Moraes, M.H., Benez, S.H., 1996. Effects of different soil tillage systems on some physical properties of terra roxa estruturada and on grain yield of corn for one year of tillage. Engenharia Agricola, 16(2): 3141.

Olsen, S.R., Cole, V., Watanabe, F.S., Dean, L.A., 1954. Estimation of available phosphorous in soils by extraction with sodium bicarbonate. USDA Circular, 9398: 1-19.
Özdemir, Ö., Gülser, C., Ekberli, İ., Kop, Ö.T., 2014. Asit toprakta düzenleyici uygulamalarının bazı toprak özellikleri ve verime etkileri. Toprak Bilimi ve Bitki Besleme Dergisi, 2(1): 27- 32.

Özyazıcı, M.A., Aydoğan, M., Bayraklı, B., Dengiz, O., 2013a. Doğu Karadeniz Bölgesi kırmız1-sarı podzolik toprakların temel karakteristik özellikleri ve verimlilik durumu. Anadolu Journal of Agricultural Sciences, 28(1): 24-32.

Özyazıc1, M.A., Dengiz, O., Sağlam, M., 2013b. Artvin ilinde yonca (Medicago sativa L.) tarımı yapılan toprakların verimlilik durumu ve potansiyel beslenme problemlerinin ortaya konulmasi. Artvin Çoruh Üniversitesi Orman Fakültesi Dergisi, 14(2): 225-238.

Raper, R.L., Reeves, D.W., Burt, E.C., Torbert, H.A., 1993. Conservation tillage and traffic effects on soil condition. Transactions of the American Society of Agricultural Engineers, 37: 763-768.

Richards, L.A., 1954. Diagnosis and improvement of saline and alkali soils. United States Department of Agriculture. Handbook, 60: 105-106.

Sağlam, M.T., 1997. Toprak ve suyun kimyasal analiz yöntemleri. Tekirdağ Üniversitesi Ziraat Fakültesi Yayınları, No: 189.

Sağlam, M., 2013. Çok değişkenli istatistiksel yöntemler ile toprak özelliklerinin gruplandırılması. Soil-Water Journal, 2(1):7-14.

Schoenholtz, S.H., Van Miegroet, H., Burger, J.A., 2000. A review of chemical and physical properties as indicators of forest soil quality: challenges and opportunities. Forest Ecology and Management, 138: 335-356.

Soba, M. R., Türkmen, F., Taşkın, M. B., Akça, M. O. ve Öztürk, H. S., 2015. Ankara Üniversitesi Ziraat Fakültesi Haymana Araştırma ve Uygulama Çiftliği topraklarının verimlilik durumlarını incelenmesi. Toprak Su Dergisi, 4(1): 7-17.

Şahin, S., 2001. Türkiye'de mısır ekim alanlarının dağılışı ve mısır üretimi. Gazi Üniversitesi Eğitim Fakültesi Dergisi, 21(1): 73-90.

Turan, M.A., Katkat, A.V., Özsoy, G., Taban, S., 2010. Bursa ili alüviyal tarım topraklarının verimlilik durumları ve potansiyel beslenme sorunlarının belirlenmesi. Uludağ Üniversitesi Ziraat Fakültesi Dergisi, 24(1): 115-130.

Turgut, İ., 2000. Bursa koşullarında yetiştirilen şeker misırında (Zea mays saccharata sturt.) bitki sıklığının ve azot dozlarının taze koçan verimi ile verim ögeleri üzerine etkisi. Turkish Journal of Agriculture and Forestry, 24: 341-347.

TÜİK, 2016. Türkiye İstatistik Kurumu Temel İstatistikler. http://www.tuik.gov.tr. (Erişim Tarihi: 20.01.2017).

Tümsavaş, Z., 2002. Bursa ili kolüvyal büyük toprak grubu topraklarının verimlilik durumunun belirlenmesi. Anadolu, Journal of Agean Agricultural Research Institute, 12(1): 131-144. 
Tümsavaş, Z., 2003. Bursa İli Vertisol büyük toprak grubu topraklarının verimlilik durumlarının toprak analizleriyle belirlenmesi. Uludağ Üniversitesi Ziraat Fakültesi Dergisi 17(2): 9-21.

Tümsavaş, Z., Aksoy, E., 2009. Kahverengi orman büyük toprak grubu topraklarının verimlilik durumlarının belirlenmesi. Uludağ Üniversitesi

Ziraat Fakültesi Dergisi, 23(1): 93-104.

United States Salinity Laboratory Staff, 1954. Diagnosis and improvement of saline and alkali soils, Agriculture. Handbook No:60, USDA.
Yağbasanlar, T., 1990. Melez buğdayın önemi ve verim potansiyeli. Çukurova Üniversitesi Ziraat Fakültesi Yayınlar1, 5: 15-24, Adana.

Yıldırım, Y., Kodal, S., 1995. Ankara koşullarından misır verimine etkileri. Ankara Üniversitesi, Ziraat Fakültesi, Tarımsal Yapılar ve Sulama Bölümü, Ankara.

Zengin, M., Şeker, C., 2003. Buğday bitkisinin besin elementi kapsamı ile toprak özellikleri arasındaki regresyon ilişkiler. Selçuk Üniversitesi Ziraat Fakültesi Dergisi, 17(31): 31-35. 